Psychology for Professional Groups

\title{
Psychology and Medicine
}




\section{Psychology for Professional Groups}

Series Editors: Antony J. Chapman and Anthony Gale

Psychology for Professional Groups is a new series of major textbooks published with the British Psychological Society. Each is edited by a teacher with expertise in the application of psychology to professional practice and covers the key topics in the training syllabus. The editors have drawn upon a series of specially commissioned topic chapters prepared by leading psychologists and have set them within the context of their various professions. A tutor manual is available for each text and includes examination questions, practical exercises and projects, further reading and general guidance for the tutor. Each textbook shows in a fresh, original and authoritative way how psychology may be applied in a variety of professional settings, and how practitioners may improve their skills and gain a deeper understanding of themselves. There is also a general tutorial text incorporating the complete set of specialist chapters and their associated teaching materials.

\section{Published with this book}

Psychology for Physiotherapists. E. N. Dunkin

\section{Subsequent titles}

Psychology and Management. Cary L. Cooper

Psychology for Social Workers. Martin Herbert

Psychology for Teachers. David Fontana

Psychology for Occupational Therapists. Fay Fransella

Psychology for Nurses and Health Visitors. John Hall

Psychology for Careers Counselling. Ruth Holdsworth

Psychology for Speech Therapists. Harry Purser

Psychology and People: A tutorial text. Antony J. Chapman and Anthony Gale 


\section{Psychology for Professional Groups}

\section{Psychology and Medicine \\ David Griffiths}

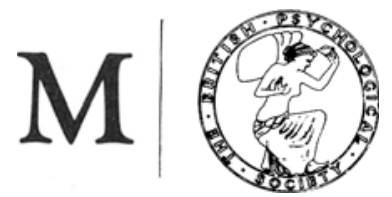


(c) The British Psychological Society 1981

Softcover reprint of the hardcover 1st edition 1981 978-0-333-31862-1

All rights reserved. No part of this publication may be reproduced or transmitted, in any form or by any means, without permission.

First published 1981 by THE BRITISH PSYCHOLOGICAL SOCIETY and THE MACMILLAN PRESS LTD.

ISBN 978-0-333-31877-5 ISBN 978-1-349-16594-0 (eBook)

DOI 10.1007/978-1-349-16594-0

The paperback version of this book is sold subject to the condition that it shall not, by way of trade or otherwise, be lent, resold, hired out, or otherwise circulated without the publisher's prior consent in any form of binding or cover other than that in which it is published and without a similar condition including this condition being imposed on the subsequent purchaser.

Note: throughout these texts, the masculine pronouns have been used for succinctness and are intended to refer to both females and males.

The conclusions drawn and opinions expressed are those of the authors. They should not be taken to represent the views of the publishers. 
To Susan, Timothy and Matthew 


\section{Contents}

Chapter 1

1 What is Psychology? Introduction

Chapter 2

16 Psychology and medicine: this book

Chapter 3

23 Biological bases of behaviour

Chapter 4

50 Abilities and behaviour in childhood and adolescence

Chapter 5

73 Social development in early childhood

Chapter 6

97 Clinical child psychology

Chapter 7

122 Ageing and social problems

Chapter 8

137 Dying and bereavement

Chapter 9

160 The family

Chapter 10

176 Institutional climates

Chapter 11

200 Personality and individual assessment

Chapter 12

239 Creating change

Chapter 13

265 Counselling and helping

Chapter 14

296 Stress

(vii) 


\section{Chapter 15}

323 Transition: understanding and managing personal change

Chapter 16

349 Pain

Chapter 17

365 Psychopathology

Chapter 18

395 What the patient should know: communication between doctors and patients

Chapter 19

404 Psychological aspects of the response to drugs

Chapter 20

417 Mental handicap

Chapter 21

434 Sexual behaviour

Chapter 22

450 Insomnia

Chapter 23

467 Obesity

485 Index 


\section{Preface}

\section{K. Rawnsley}

British medical schools nowadays include psychology in the undergraduate curriculum, though the subject attracts mixed feelings both from students and from some members of staff. Its 'relevance', as indeed that of other basic sciences, may not dawn until the student has first-hand experience of clinical life. He may then begin to realize that he is perforce dealing with complex sentient beings (including himself) and that diagnosis and treatment depend upon much more than a knowledge of anatomy, physiology and pathology.

By that time it is not necessarily too late and the present book, if he has not already encountered it, will of fer him a most readable, up-to-date and expert review of many areas of psychology bearing upon clinical medicine. The young student, in his early peregrination of the wards, may well turn initially to the chapter by Griffiths on communication between doctors and patients. He is, after all, placing his foot upon the first rung of a ladder which he will continue to climb throughout the whole of his medical career - learning clinical skills of which the linch-pin is interviewing. If he is puzzled by the strange ways in which patients and staff behave in hospital settings he will find illumination in Orford's chapter on institutional climates.

During his paediatric clerkship there are several chapters of immediate relevance on abilities and behaviour (Foss); social development (Schaffer); and clinical child psychology (Griffiths).

When working on the medical and surgical wards and in the out-patient departments he will be impressed by the high proportion of elderly patients and the chapter by Coleman offers a sensitive and valuable perspective. He may realize early on that the giving and receiving of drugs and the response to these substances involves more than can be understood in purely chemical terms. Griffiths' chapter on this topic will interest him.

Many students have their first experience of death during the clinical years. They will have to cope with their own feelings on encountering patients with fatal illnesses and they may or may not be helped by their seniors. Carr's chapter on death and bereavement will provide some insight. 
Traditionally students are brought up in the orderly antiseptic world of the teaching hospital with the emphasis on high technology medicine and on the study of patients divorced from their natural habitat. General practice, however, is what most students will eventually do after qualification and so, belatedly, this is being incorporated in a small way into the undergraduate menu. It is in this setting par excellence that the medical student will appreciate the ubiquity of 'psychological problems'. Several chapters have an immediate bearing: counselling and helping (Hopson); psychopathology (Shapiro); insomnia, obesity, sexual behaviour (all by Griffiths); the family (Frude); underst anding and managing personal change (Hopson); stress (Griffiths); pain (Ray).

Psychological medicine, a peculiarly British term, though permeating throughout clinical medicine, retains as its main focus the study and management of mental disorders. Psychology, of course, has a very special link with this discipline and the student will find valuable material in the chapter on personality and individual assessment (Kline); how human behaviour is changed (Beech); biological bases of behaviour (Martin) and mental handicap (Griffiths).

Some doctors, like some children, are late developers but may make up for lost time and even surpass their peers. This book, capably edited by David Griffiths and written with understanding and skill by a team of carefully selected contributors, will facilitate their growth admirably.

Kenneth Rawnsley

Department of Psychological Medicine

Welsh National School of Medicine

Cardiff 


\section{Foreword}

This book is one of a series, the principal aims of which are to illustrate how psychology can be applied in particular professional contexts, how it can improve the skills of practitioners, and how it can increase the practitioners' and students' understanding of themselves.

Psychology is taught to many groups of students and is now integrated within prescribed syllabuses for an increasing number of professions. The existing texts which teachers have been obliged to recommend are typically designed for broad and disparate purposes, and consequently they fail to reflect the special needs of students in professional training. The starting point for the series was the systematic distillation of views expressed in professional journals by those psychologists whose teaching specialisms relate to the applications of psychology. It soon became apparent that many fundamental topics were common to a number of syllabuses and courses; yet in general introductory textbooks these topics tend to be embedded amongst much superfluous material. Therefore, from within the British Psychological Society, we invited experienced teachers and authorities in their field to write review chapters on key topics. Forty-seven chapters covering 23 topics were then available for selection by the series' Volume Editors. The Volume Editors are also psychologists and they have had many years of involvement with their respective professions. In preparing their books, they have consulted formally with colleagues in those professions. Each of their books has its own combination of the specially-prepared chapters, set in the context of the specific professional practice.

Because psychology is only one component of the various training curricula, and because students generally have limited access to learned journals and specialist texts, our contributors to the series have restricted their use of references, while at the same time providing short lists of annotated readings. In addition, they have provided review questions to help students organize their learning and prepare for examinations. Further teaching materials, in the form of additional references, projects, exercises and class notes, are available in Tutor Manuals prepared for each book. A comprehensive tutorial text ('Psychology and People'), prepared by the Series Editors, combines in a 
single volume all the key topics, together with their associated teaching materials.

It is intended that new titles will be added to the series and that existing titles will be revised in the light of changing requirements. Evaluative and constructive comments, bearing on any aspect of the series, are most welcome and should be addressed to us at the BPS in Leicester.

In devising and developing the series we have had the good fortune to benefit from the advice and support of $\mathrm{Dr}$ Halla Beloff, Professor Philip Levy, Mr Allan Sakne and Mr John Winckler. A great burden has been borne by Mrs Gail Sheffield, who with skill, tact and courtesy, has managed the production of the series: to her and her colleagues at the BPS headquarters and at the Macmillan Press, we express our thanks.

Antony J. Chapman

UWIST, Cardiff

Anthony Gale

University of Southampton

May 1981 